\title{
Kondisi Pendidikan Berwawasan Lingkungan Berbasis Kearifan Lokal Masyarakat Suku Dayak Kalimantan Tengah Tahun 2018
}

\author{
Muh. Azhari \\ Program Studi Teknik Lingkungan Universitas Muhammadiyah Palangkaraya \\ *email: arymuh@gmail.com
}

\begin{abstract}
ABSTRAK. Kalimantan Tengah merupakan salah satu gugus kepulauan di Indonesia dengan kondisi lingkungan yang khas. Lingkungan yang khas menjadi identitas yang melekat bagi sumberdaya yang terkandung di dalamnya, baik sumberdaya alam maupun sumberdaya manusia. Pengenalan lingkungan setempat harus dilakukan, guna meningkatkan kesadaran dan kecintaan terhadap lingkungan sekitar, misalnya melalui kegiatan pendidikan berwawasan lingkungan berbasis kearifan lokal (masyarakat Suku Dayak Kalimantan Tengah). Pendidikan merupakan hak bagi setiap warga negara. Amanah tersebut tercantum pada Undang-Undang Dasar 1945 Pasal 31 Ayat 1. Hasil penelitian yang dilakukan dengan cara survey jenis panel survey bertujuan untuk mengetahui gambaran umum mengenai materi lingkungan yang diberikan di ranah pendidikan misalkan di sekolah menengah atas (SMA) khususnya di Kalimantan Tengah Tentang Kearifan Lokal Masyarakat Suku Dayak. Hasil yang diperoleh dalam kegiatan penelitian yaitu tidak adanya materi yang khusus tentang lingkungan setempat (misal Lingkungan Suku Dayak Kalimantan Tengah) materi yang diberikan masih bersifat lingkungan umum yang ada di Indonesia atau dari negara-negara lainnya.
\end{abstract}

Kata kunci: Pendidikan, Lingkungan, Suku Dayak, Kearifan Lokal

\section{PENDAHULUAN}

Pendidikan merupakan hak setiap warga negara seperti yang diamantkan dalam Undang-Undang Dasar 1945 Pasal 31 ayat 1. Pendidikan berwawasan lingkungan berbasis kearifan lokal merupakan salah satu kekayaan pendidikan yang harus disampaikan kepada masyarakat, khusnya masyarakat yang memiliki kearifan tersebut dan umumnya masyarakat Indonesia dan dunia, sehingga semua orang tahu mengenai kearifan lokal lingkungan yang ada dan di jadikan sebagai salah satu kekayaan informasi untuk dipelajari dan dijaga.

Pengetahuan tentang lingkungan setempat dengan kearifan lokal yang ada sangat penting sekali untuk dipelajari, terutama untuk penduduk yang tinggal di lingkungan tersebut, karena dengan mengetahui kondisi lingkungan sekitar akan menyiapkan masyarakat setempat untuk menjaga lingkungannya dari segala kemungkinan yang merugikan lingkungan tempat tinggal. Misalnya seperti kebakaran, kabut asap, banjir, kekeringan dan tanah longsor bahkan gunung meletus dan gempa bumi.

Pengetahuan tentang lingkungan berbasis kearifan lokal setempat bagi masyarakat dapat dijadikan sebagai salah satu alat mitigasi pencegahan bencana, menjadi agen vioner yang sigap dan tanggap terhadap kondisi lingkungan. Misalnya lingkungan yang ada di Kalimantan Tengah. Kalimantan Tengah merupakan salah satu Provinsi yang 
ada di Indonesia dengan pusat pemerintahan administrasi di Kota Palangka Raya.

Atmosfir Kalimantan Tengah yang kadang-kadang kurang kondusif karena adanya bencana lingkungan yang terjadi mengharuskan adanya kegiatan pendidikan berwawasan lingkungan berbasis kearifan lokal setempat.

Aktivitas yang dilakukan oleh manusia akan berpengaruh terhadap kondisi lingkungan tempat manusia melaksanakan aktivitas tersebut. Misalnya kerusakan lingkungan, baik lingkungan air, tanah, dan udara. Pengerusakan lingkungan hidup menurut UU No 32 Tahun 2009 adalah tindakan orang yang menimbulkan perubahan langsung atau tidak langsung terhadap sifat fisik, kimia dan/atau hayati lingkungan hidup sehingga melampaui kriteria baku kerusakan lingkungan hidup. Perlu diketahui bahwa lingkungan hidup merupakan kesatuan ruang dengan semua benda, daya, keadaan, dan makhluk hidup, termasuk manusia dan perilakunya, yang mempengaruhi alam itu sendiri, kelangsungan perikehidupan, dan kesejahteraan manusia serta makhluk hidup lain. sehingga di perlukan perlindungan dan pengelolaan lingkungan hidup yang tepat.

UU No. 32 Tahun 2009 Tentang perlindungan dan pengelolaan lingkungan hidup menyebutkan bahwa perlindungan dan pengelolaan lingkungan hidup merupakan upaya sistematis dan terpadu yang dilakukan untuk melestarikan fungsi lingkungan hidup dan mencegah terjadinya pencemaran dan/atau kerusakan lingkungan hidup yang meliputi perencanaan, pemanfaatan, pengendalian, pemeliharaan, pengawasan, dan penegakan hukum. Hal ini beriringan dengan mitigasi bencana yang merupakan serangkaian upaya untuk mengurangi risiko bencana, baik melalui peningkatan kemampuan menghadapi ancaman bencana (PP No. 21 tahun 2008 Pasal 1 ayat 6 tentang penyelenggaraan penanggulangan bencana).

Berdasarkan hal tersebut maka perlu dilakukan atau dilaksanakan mengenai pendidikan berwawasan lingkungan berbasis kearifan lokal masyarakat Suku Dayak kalimantan Tengah Tahun 2018 sebagai salah satu cara meminimalisir risiko bencana lingkungan yang terjadi di Kalimantan Tengah. Tujuan dari penelitian ini yaitu:

1. Untuk mengetahui bentuk materi pembelajaran tentang lingkungan yang diajarkan di Sekolah Menengah Atas yang ada di Kalimantan Tengah.

2. Mengetahui kondisi pendidikan berwawasan lingkungan berbasis kearifan lokal masyarakat Suku Dayak Kalimantan Tengah yang diajarkan di Sekolah Menengah Atas.

\section{TINJAUAN PUSTAKA}

\section{A. Lingkungan}

Lingkungan adalah suatu sistem kompleks yang berada di luar individu yang mempengaruhi pertumbuhan dan perkembangan organisme. Lingkungan tidak sama dengan habitat. Habitat adalah tempat di mana organisme atau komunitas organisme hidup (Setyono, 2008).

Lingkungan merupakan sistem terintegrasi antar komponen abiotik dan biotik yang keduanya berada pada kondisi hubungan kompensatif dan menghasilkan keharmonisan sistem. Lingkungan merupakan sistem yang di dalamnya bekerja subsistem-subsistem baik subsistem abiotik maupun biotik dan berlangsungnya proses alih rupa (transformation) dan alih tempat (translocation) yang dipicu oleh proses pertukaran energi dan bahan/materi antar subsistem tersebut. Subsistem abiotik meliputi atmosfer, pedhosfer/lithosfer dan hidrosfer, sedangkan subsistem biotik merupakan semua makhluk hidup atau organisme dengan seluruh bentuk interaksi yang terjadi (Budiastuti, 2010).

Dalam buku Teologi Lingkungan (Kementerian Lingkungan Hidup, 2011) lingkungan sebagai suatu keadaan atau kondisi alam yang terdiri atas benda-benda (makhluk) hidup dan benda-benda tak hidup yang berada di bumi atau bagian dari bumi secara alami dan saling berhubungan antara satu dengan lainnya.

\section{B. Kearifan Lokal}

Menurut Putu Oka Ngakan dalam Andi M Akhmar dan Syarifudin (2007) kearifan lokal merupakan tata nilai atau 
perilaku hidup masyarakat lokal dalam berinteraksi dengan lingkungan tempatnya hidup secara arif. Sementara itu menurut Keraf (2002) menegaskan bahwa kearifan lokal adalah semua bentuk pengetahuan, keyakinan, pemahaman atau wawasan serta adat kebiasaan atau etika yang menuntun perilaku manusia dalam komunitas ekologis. Semua bentuk kearifan lokal ini dihayati, dipraktekan, diajarkan dan diwariskan dari generasi ke generasi sekaligus membentuk pola perilaku manusia terhadap sesama manusia, alam maupun gaib.

Selanjutnya Francis wahono (2005) menjelaskan bahwa kearifan lokal adalah kepandaian dan strategi-strategi pengelolaan alam semesta dalam menjaga keseimbangan ekologis yang sudah berabad-abad teruji oleh berbagai bencana dan kendala serta keteledoran manusia. Kearifan lokal tidak hanya berhenti pada etika, tetapi sampai pada norma dan tindakan dan tingkah laku, sehingga kearifan lokal dapat menjadi seperti religi yang memedomi manusia dalam bersikap dan bertindak, baik dalam konteks kehidupan sehari-hari maupun menentukan peradaban manusia yang lebih jauh.

Definisi kearifan lokal dalam Undangundang No.32 tahun 2009 tentang Pengelolaan dan Perlindungan Lingkungan Hidup adalah nilai-nilai luhur yang berlaku dalam tata kehidupan masyarakatuntuk antara lain melindungi dan mengelola lingkungan hidup secara alami.

\section{Suku Dayak}

Nila Riwut, 2003 mengatakan bahwa Kalimantan berarti pulau yang memiliki sungai-sungai besar dan pulau terbesar ke tiga setelah Green Land dan irian Jaya. Sebagai kolonialisme barat, bekas wilayah inggris di utara, menjadi wilayah negara malaysia dan kesultanan Brunei, sedangkan bekas jajahan Belanda di selatan menjadi wilayah Republik Indonesia yang terbagi menjadi empat propinsi, yaitu Kalimantan Barat, Kalimantan Timur, Kalimantan selatan dan Kalimantan Tengah. Sebutan kata Dayak adalah sebutan umum di Kalimantan bahkan di seluruh Indonesia, setiap orang yang mendengar kata dayak sudah tentu pandangannya tertuju kepada salah satu suku di Indonesia yang mendiami Kalimantan. Terlihat adanya perbedaan-perbedaan pendapat bahwa suku dayak berasal berasal dari langit ke tujuh dan ada pula yang bependapat dahwa orang dayak berasal dari proto melayu. Menurut keyakinan orang dayak yang berasal dari kepercayaan kaharingan, manusia diturunkan dari langit ke tujuh di empat tempat, yaitu:

1. Di Tantan puruk Pamatuan, yang terletak di hulu sungai Kahayan dan Barito

2. Di Tantang liang Mangan Puruk Kaminting yang letaknya di sekitar Gunung Raya.

3. Di Datah Tangkasiang, di hulu sungai malahui, yang terletak di daerah Kalimantan Barat.

4. Di Puruk Kambang Tanah Siang yang terletak di hulu sungai Barito.

Orang-orang Dayak yang diturunkan di tempat-tempat ini, saling kawin mengawinsatu dengan lainnya, lalu berkembang biak menempati seluruh pulau kalimantan. Secara ilmiah kurang lebih dua ratus tahun sebelum masehi, terjadilah perpindahan bangsa melayu yang pertama ke Indonesia. Mereka datang secara bergelombang dari daerah yunan.

Suku dayak kebanyakan berdiam di daerah pedalaman dan tidak banyak yang mendiami daerah pesisir. Setiap suku memiliki bahsa daerah masing-masing, bahkan bahasa daerah dari suu yang berada di daerah yang letaknya tidak jauh, juga berbeda. Sebagai contoh, di daerah kahayan dan Kapuas dari muara sungai sampai kurang lebih dua pertiga bagian Sungai Kahayan, penduduknya menggunakan bahasa Dayak Nagju. Sementara itu di bagian hulu, bahasa yang digunakan ialah bahasa Dayak Ot. Danom. Suku Dayak di Kalimantan terdiri atas tujuh suku. Ke tujuh suku ini terdiri dari delapan belas anak suku yang sedatuk, yang terdiri dari 405 suku kekeluargaan.

\section{HASIL DAN PEMBAHASAN}

Hasil penelitian tentang kondisi pendidikan berwawasan lingkungan yang berbasis kearifan lokal masyarakat Suku Dayak Kalimantan Tengah tahun 2018 yaitu materi yang diajarkan pada setiap jenjangnya 
misalnya seperti kelas X, XI, dan XII pada mata pelajaran Biologi tentang pengetahuan lingkungan masih membahas materi tentang lingkungan secara umum.

Lingkungan pada masing-masing daerah memiliki karakteristik yang unik. Karakteristik tersebut menjadi identitas bagi daerah tersebut. misalnya daerah Kalimantan Tengah terkenal dengan daerah gambut dan rawa. Kalimantan Tengah beberapa tahun belakangan juga sering terkena bencana lingkungan seperti kebakaran lahan hutan dan kebun, banjir di beberapa daerah seperti Kota Palangka Raya, dan bencana kabut asap.

Permasalahan tersebut tentu merugikan banyak orang baik kerugian material ataupun kerugian non material. Jika bencana tersebut terus di biarkan akan menimbulkan kekhawatiran bagi masyarakat yang tinggal di lingkungan tersebut. tentunya ketakutan akan bencana yang terjadi sewaktuwaktu dan mengancam jiwa masyarakat sekitar.

Bencana yang terjadi dapat diminimalisir yaitu dengan menyelenggarakan pendidikan berwawasan lingkungan berbasis kearifan lokal masyarakat setempat. Misalnya kearifan lokal yang dimiliki oleh masyarakat Suku Dayak Kalimantan Tengah. diantara kearifan lokal yang dimiliki oleh masyarakat Suku Dayak Kalimantan Tengah berdasarkan beberapa sumber literatur seperti kegiatan jipen, jipen tersebut dilaksanakan apabila ada kegiatan atau perbuatan yang tidak sesuai dan dianggap merugikan atau merusak lingkungan.

Materi yang diajarkan di beberapa tingkatan atau jenjang pendidikan perlu menampilkan materi tentang kondisi lingkungan setempat dengan karakteristik lingkungan yang ada, sehingga para peserta didik lebih memahami lingkungan tempat tinggalnya. Di harapkan para peserta didik tersebut dapat menjadi vioner penjaga keselamatan lingkungan. Akan tetapi materi yang ada misalnya di salah satu mata pelajaran yang ada (biologi) masih mengajarkan materi pembelajaran umum tentang pengetahuan lingkungan.

\section{KESIMPULAN}

Materi pembelajaran tentang lingkungan yang diajarkan pada peserta didik terutama di tingkat Sekolah Menengah Atas masih bersifat umum, belum spesifik membahas tentang kondisi lingkungan yang ada di masing-masing daerah seperti di daerah Kalimantan Tengah, sehingga langkah mitigasi pencegahan bencana, jika bencana lingkungan terjadi belum dapat dilakukan tindakan yang tepat oleh penduduk sekitar lingkungan tersebut, dengan demikian masyarakat akan menunggu aparat yang berwenang untuk menyelesaikan masalah lingkungan tersebut.

\section{SARAN}

Perlu dibuat materi pembelajaran yang khusus mengenai pengetahuan lingkungan dengan kondisi lingkungan dimana materi tersebut di ajarkan, misalnya di kalimantan Tengah, maka karakteristik materi lingkungan yang diajarkan berbasis lingkungan Kalimantan Tengah, sehingga materi yang diperoleh dengan mudah diaplikasikan oleh masyarakat setempat (dapat menjadi vioner pelindung lingkungan setempat dari bencana lingkungan yang tidak diinginkan)

\section{DAFTAR PUSTAKA}

Arif, Z. (2014), Dasar-Dasar Ilmu Lingkungan. Salemba Teknika. Jakarta.

Bruce, M. B, Setiawan. Dwita, H.R. (2007), Pengelolaan Sumberdaya dan Lingkungan. Gadjah Mada University Press. Yogyakarta.

Hermanto,S. (2011). Makalah Mekanisme Pelepasan Kawasan Hutan dan Pinjam Pakai Kawasan Hutan. Dinas Kehutanan Provinsi Kalimantan Tengah. Palangka Raya.

Peraturan Pemerintah Republik Indonesia No.
21 Tahun 2008 Tentang
Penyelenggaraan Penanggulangan
Bencana.

Pumpung, Hai. (2014). Buku Panduan Pumpung Hai Pakat Dayak dan Napak Tilas Pakat Damai Tumbang Anoi. Palangka Raya. 
Undang-Undang Dasar Republik Indonesia Tahun 1985.

Undang-Undang Republik Indonesia No. 24 Tahun 2007 Tentang Penanggulangan Bencana.

Undang-Undang Republik Indonesia No. 32 Tahun 2009. (2014). Perlindungan dan Pengelolaan Lingkungan Hidup. Kementerian Lingkungan Hidup. Jakarta. 